Cakrawala Dini: Jurnal Pendidikan Anak Usia Dini | p-ISSN 2087-I317| e-ISSN 262I-8321

Vol. I0. No.2 November 2019 | Hal 93-100

\title{
PENANAMAN NILAI KARAKTER MELALUI PEMBIASAN BERBAHASA JAWA PADA ANAK USIA DINI DI DESA TANGGERAN, KABUPATEN BANYUMAS
}

\author{
Wahyu Trisnawati ${ }^{1}$, Puji Yanti Fauziah ${ }^{2}$ \\ ${ }^{1,2}$ Universitas Negeri Yogyakarta
}

\begin{abstract}
For Javanese people, Javanese is a language used in everyday interactions. Through the habituation of using Javanese language there is a character value in the child, including the value of courtesy and uploading it when communicating with older people. In the digital era the use of Javanese is increasingly fading, not only in everyday language but also in institutional institutions, especially educational institutions. The purpose of this study was to determine family parenting in growing character in early childhood through habituation to Javanese. The method used is descriptive qualitative. Family becomes a central point in the process of developing character values in children. Parenting style determines how the development of children's character values, and can be monitored through the habit of using Javanese language in daily interactions, both Javanese ngoko or Javanese language. Parents provide a stimulus for children to hone the habit of using Javanese in daily interactions. Effective parenting practices in fostering character values in children are democratic parenting, parents not only provide facilities to children, but still monitor and supervise children.
\end{abstract}

Keywords: Character Value, Javanese Language, Early Childhood

\begin{abstract}
Abstrak: Bagi masyarakat Jawa, bahasa Jawa merupakan bahasa yang digunakan dalam berinteraksi sehari-hari. Melalui pembiasaan menggunakan bahasa Jawa terkandung nilai karakter dalam diri anak, diantaranya adalah nilai sopan santun dan unggah ungguh ketika berkomunikasi dengan orang yang lebih tua. Di era digital penggunaan bahasa Jawa semakin memudar, tidak hanya dalam bahasa sehari-hari tetapi juga dalam instansi kelembagaan, khususnya lembaga pendidikan. Tujuan dalam penelitian ini adalah untuk mengetahui pola asuh keluarga dalam menumbuhkan karakter pada anak usia dini melalui pembiasaan berbahasa Jawa. Metode yang digunakan adalah deskriptif kualitatif. Keluarga menjadi titik sentral dalam proses perkembangan nilai karakter pada anak. Pola asuh orang tua menentukan bagaimana perkembangan nilai karakter anak, dan dapat dipantau melalui pembiasaan menggunakan bahasa Jawa dalam interaksi sehari-hari, baik bahasa Jawa ngoko atau bahasa Jawa karma. Orang tua memberikan stimulus pada anak untuk mengasah pembiasaan menggunakan bahasa Jawa dalam interaksi sehari-hari. Pola asuh yang efektif diterapkan dalam menumbuhkan nilai karakter pada anak adalah pola asuh demokratis, orang tua tidak hanya memberikan fasilitas pada anak, tetapi masih memantau dan mengawasi anak.
\end{abstract}

Kata Kunci: Nilai Karakter, Bahasa Jawa, Anak Usia Dini

\footnotetext{
${ }^{1}$ Universitas Negeri Yogyakarta, Email: wahyutrisnawati.2018 @student.uny.ac.id

${ }^{2}$ Universitas Negeri Yogyakarta, Email: pujiyanti回uny.ac.id
} 


\section{PENDAHULUAN}

Perkembangan zaman yang semakin modern, memberikan dampak terhadap kehidupan kita, khususnya pada pertumbuhan dan perkembangan budaya. Semakin berkembangnya kebudayaan nasional, menyebabkan semakin sedikit anak yang memahami secara mendalam mengenai kebudayaan lokal. Tumbuh dan berkembangnya anak sangat tergantung pada pola asuh yang diterapkan oleh orang tuanya di rumah. Anak usia dini lebih banyak menghabiskan waktunya di rumah daripada di sekolah. Perbedaan pola asuh yang diterapkan, akan berbeda juga sikap dan perilaku anak dalam perkembangannya. Lingkungan keluarga merupakan lingkungan pertama anak dalam hal memperoleh pendidikan, lingkungan dimana anak dapat tumbuh dan berkembang dengan pemantauan dan pengawasan orang tua dan anggota keluarga lainnya yang hidup satu rumah dengannya. Selain keluarga, pendidik juga memegang peran penting dalam menumbuhkembangkan anak, khsuusnya dalam mengembangkan nilai karakter anak. Berdasarkan hasil penelitian (Aprilianidkk, 2019) menyatakan bahwa orang tua yang menerakan tata karma dari budaya jawa berusaha mengajarkan bahasa dan sikap orang jawa yang sudah melekat menjadi budaya jawa pada anak usia dini. Orang tua memiliki tanggung jawab dalam pembentukan sikap anak, dan hasilnya dapat dilihat ketika anak berinteraksi di lingkungan sekolah atau lingkungan masyarakat sekitar. Orang tua terlebih dulu memberi contoh pada anak saat beinteraksi di lingkungan masyarakat, secara tidak langsung anak akan menirukan apa yang dilakukan oleh orang tuanya.

Penanaman nilai karater perlu dibentuk dan ditanamkan sejak usia dini. Jika nilai karakter sudah tertanam sejak usia dini, maka sulit untuk merubah karakter tersebut. Usia dini merupakan masa emas dalam pembentukan karakter sebagai bekal di masa mendatang.
Pendidikan karakter tidak dominan diajarkan pada tingkat Penidikan Anak Usia Dini (PAUD) tetapi nilai pendidikan karakter perlu diberikan dalam porsi yang besar dari porsi pembelajaran yang mengarahkan pada kognitif anak. Masa golden age merupakan masa pembentukan karakter anak yang sesungguhnya, dan akan terbawa sampai mereka dewasa. Perkembangan anak, terkadang terhambat karena permasalahan yang ada pada diri mereka sendiri. Selain itu, juga dikarenakan oleh orang-orang disekitar anak, misalnya karena pola asuh orang tua. Pendidik di sekolah berusaha mengajarkan anak supaya anak dapat berkembang sesuai dengan tahapan usianya, tetapi apa yang diajarkan oleh pendidik di sekolah dan apa yang diajarkan di lingkungan rumah belum tentu mempunyai maksud yang sama. Sebagian besar orang tua mengajarkan anak di rumah menggunakan Bahasa Indonesia untuk berinteraksi dengan anggota keluarga atau orang-orang di sekitarnya, ada juga orang tua yang menerapkan campuran bahasa Indonesia dan bahasa Jawa dalam berinteraksi dengan anak. Sekarang sudah jarang orang tua yang berinteraksi dengan anaknya mengunakan bahasa Jawa, khsuusnya bahasa Jawa krama.

Keluarga menjadi titik sentral pembentukan karakter anak, tetapi pada kenyataannya sebagian besar keluarga menyerahkan kepada pendidik di lembaga sekolah untuk masalah perkembangan anak. Keluarga masih kurang antusias dalam membentuk karakter anak, dan ikut berperan dalam proses perkembangan anak. Sumber daya manusia yang masih rendah, dan kurangnya sosialisasi mengenai pentingnya perkembangan anak di usia golden age, menjadikan keluarga kurang memperhatikan perkembangan anaknya. Keluarga lebih menganut pola asuh yang diajarkan oleh keluarganya secara turun temurun. Bahasa Jawa menjadi salah satu Budaya Jawa yang harus dilestarikan. 
Semakin banyaknya keluarga yang menerapkan Bahasa Indonesia dalam komunikasi dengan anak, dan anak kurang memahami Bahasa Jawa yang sudah menjadi Budaya di masyarakat. Sebelum membelajarkan anak mengenai Bahasa Jawa, maka orang tua perlu memahaminya, dan belajar sungguhsungguh untuk dapat mengajarkan pada anak. Sikap dan tindakan anak tergantung pada pola asuh yang diterapkan oleh orang tuanya. Sebagai orang tua perlu memperhatikan unggah-ungguh dalam bertindak, dalam berkomunikasi dengan orang-orang di sekitarnya atau orangorang yang lebih tua. Penerapan bahasa jawa pada anak, baik di lingkungan keluarga atau lingkungan masyarakat akan mempengaruhi perilaku atau sikap anak yang sesuai dengan nilai pendidikan yang ditanamkan pada keluarga jawa melalui pola asuh orang tua. Anak pada dasarnya dapat menangkap bahasa orang tua, dan orang-orang disekitarnya sejak ia berada di dalam kandungan (Dardjowidjojo, 2010). Namun aplikasi dari bahasa anak yakni ketika anak dilahirkan, anak akan menangkap bahasa ayah dan ibunya, serta lingkungan di sekitar anak tinggal.

Dari hasil pengamatan yang dilakukan oleh peneliti, peneliti tertarik untuk melakukan penelitian mengenai penanaman nilai karakter melalui pembiasaan berbahasa jawa pada anak usia dini di Desa Tanggeran, Kabupaten Banyumas. Dapat diambil rumusan masalah "Bagaimana pola asuh keluarga dalam menanamkan nilai karakter pada anak usia dini melaui pembiasaan berbahasa jawa?" dan tujuan penelitian ini adalah untuk melihat bagaimana pola asuh orang tua dalam menanamkan nilai karakter pada anak melalui pembiasaan berbahasa jawa pada anak usia dini di Desa Tanggeran, Kanupaten Banyumas.

\section{METODOLOGI PENELITIAN}

Jenis penelitian yang digunakan oleh peneliti adalah penelitian deskriptif kualitatif. Menurut (Sugiyono, 2013), penelitian kualitatif merupakan metode penelitian yang digunakan untuk meneliti kondisi objek yang alamiah, dimana peneliti adalah sebagai instrument kunci, teknik pengumpulan data dilakukan secara triangulasi, analisis data bersifat induktif, serta hasil penelitian kualitatif lebih menekankan pada makna daripada generalisasi. Adapun menurut Creswell pendekatan kualitatif merupakan salah satu ciri khusus dari penelitian kualitatif adalah dengan mendeskripsikan permasalahan penelitian melalui deskripsi tren atau kebutuhan akan penjelasan tentang hubungan antara beberapa variabel (Creswell, 2015).Penelitian ini menggunakan pendekatan kualitatif karena penelitian berhubungan dengan fenomena sosial di masyarakat, yakni menganalisis bagaimana pola asuh keluarga dalam menanamkan nilai karakter pada anak usia dini melalui pembiasaan berbahasa jawa pada anak usia dini di Desa Tanggeran, Kabupaten Banyumas.

\section{Variabel Penelitian}

Variabel dalam penelitian yang dilakukan oleh peneliti yakni penanaman nilai karakter melalui pembiasaan berbahasa jawa pada anak usia dini.

\section{Lokasi Penelitian}

Penelitian ini dilaksanakan di lingkungan masyarakat Desa Tanggeran, Kecamatan Somagede, Kabupaten Banyumas.

\section{Waktu Penelitian}

Peneliti melaksanakan penelitian pada bulan April 2019.

\section{Subjek Penelitian}

Keluarga yang memiliki anak usia dini, dan berdomisili di Desa Tanggeran, Kabupaten Banyumas.

\section{Prosedur}

Prosedur dalam penelitian ini adalah sebagai berikut: 1) Observasi lapangan; 
2) Penyusunan instrument; 3) Pengambilan data penelitian; 4) Analisis data penelitian.

\section{Instrumen}

Instrumen dalam pengumpulan data penelitian adalah peneliti sendiri, dalam penelitian ini peneliti sebagai kunci untuk mengembangkan instrument observasi.

\section{Teknik Pengumpulan Data}

Teknik pengumpulan data dalam penelitian yaitu dengan observasi partisipan.

\section{Teknik Analisis Data}

Analisis data dalam penelitian ini menggunakan teknik analisis menurut Milles dan Huberman dalam (Sugiyono, 2013) yang terdiri dari data reduksi, data display, dan conclusing drawing.

Data Reduksi

Reduksi data adalah kegiatan merangkum, memilih hal-hal pokok, memfokuskan pada hal-hal yang penting, mencari tema dan polanya serta membuang yang tidak perlu baik iu dari hasil observasi atau dokumentasi.

Data Display

Penyajian data dalam penelitian ini dilakukan dalam bentuk uraian singkat dan teks naratif.

Conclusing drawing

Pada bagian ini peneliti menarik kesimpulan dari data yang telah diperoleh. Penarikan kesimpulan diperoleh dengan membandingkan hasil penelitian dengan kajian teori dari penelitian ini.

\section{HASIL PENELITIAN DAN PEMBAHASAN \\ Pola Asuh Orang Tua}

Sochib, (2000) menyatakan bahwa pola asuh adalah sesuatu yang fundamental dalam pembentukan karakter anak. Sikap orang tua akan menjadi contoh pada anaknya, karena anak usia dini melakukan modeling, dan imitasi dari lingkungan terdekatnya, yakni lingkungan keluarga. Keterbukaan pendapat dan nasehat antara orang tua dengan anak akan menghindarkan anak pada perilaku negative yang ada pada lingkungan sekitar, atau lingkungan masyarakat dimana anak berinteraksi dengan teman-teman sebaya di lingkungannya yang memiliki sikap dan kebiasaan yang berbeda di dalam lingkungan keluarga. Orang tua memiliki tanggung jawab untuk membantu anak dalam hal pembiasaan diri dengan hal-hal yang positif.

Sedangkan Faisal (2016) mendefinisikan pola asuh sebagai pola interaksi antara orang tua dengan anak, meiputi pemenuhan kebutuhan fisik, psikologis, dan sosialisasi norma yang berlaku dalam masyarakat dengan tujuan supaya anak dapat mematuhi aturan yang berlaku di lingkungannya.

Menurut Edward (2006) pola asuh orang tua dipengaruhi oleh beberapa faktor, yakni: pendidikan orang tua, lingkungan,dan budaya. Karakter anak diajarkan melalui sikap anggota keluarganya yang dijadikan percontohan bagi diri anak. Pembentukan karakter anak sangat dipengaruhi oleh model pola asuh yang diterapkan oleh orang tua. Berdasarkan hasil observasi dan wawancara yang dilakukan oleh peneliti, sebagian besar orang tua menerapkan pola asuh sesuai dengan pengetahuan mereka mengenai perkembangan anak. Pendidikan orang tua sangat berpengaruh dalam pembentukan sikap anak melalui pola asuh yang diterapkan. Orang tua yang menempuh pendidikan sampai tingkat SMP begitu kurang memperhatikan perkembangan anak, dan anak kurang menerapkan unggah ungguh yang ada di lingkungan masyarakat. Sedangkan orang tua yang menempuh pendidikan sampai tingkat SMA, lebih memperhatikan anak, tidak hanya memfasilitasi kebutuhan anak tetapi memantau perkembangan dan mengawasi sikap dan tingkah laku anak. Orang tua lebih memahami berbahasa jawa yang 
baik dan benar, dan mengaplikasikan belajar berbahasa pada anak sejak usia 1 tahun. Walaupun ketika anak memasuki dunia pendidikan, bahasa keseharian yang biasanya menggunakan bahasa Jawa dan bercampur dengan bahasa Indonesia yang merupakan bahasa nasional, dan lebih sering digunakan oleh pendidik di PAUD.

Hurlock (2000) membagi pola asuh orang tua dalam tiga tipe, yakni pola asuh demokratis, pola asuh otoriter, dan pola asuh permisif.

1. Pola asuh demokratis

Gunarsa (2002) menyatakan bahwa penanaman sikap disiplin pada anak, orang tua perlu menerapkan pola asuh demokratis, dimana orang tua mempunyai hak untuk menghargai akan kebebasan anak, melalui bimbingan dengan penuh pengertian antara orang tua dengan anak, memberikan pengertian pada anak ketika anak melontarkan pendapat yang tidak sesuai dengan pemikiran orang tua. Melalui pengasuhan demokratis, anak akan memiliki sikap tanggung jawab dan mampu bertindak sesuai dengan norma yang berlaku di lingkungan keluarga dan lingkungan masyarakat.

\section{Pola asuh otoriter}

Gunarsa (2002) mendefinisikan pola asuh otoriter sebagai pola perilaku orang tua yang menerapkan aturan dan batasan-batasan yang mutlak dan memiliki keharusan untuk ditaati oleh anak. Orang tua tidak memberikan kesempatan anak untuk menyampaikan argumen atau pendapatnya mengenai sesuatu hal, dan ketika anak tidak mematuhi aturan yang dibuat oleh orang tuanya maka orang tua akan memberikan hukuman pada anak. Pola asuh otoriter yang diterapkan oleh orang tua pada anak, akan menghilangkan kebebasan pada anka untuk bertindak, dan anak merasa terkekang karena dimasa anak usia dini mereka membutuhkan waktu kebebasan untuk mengeksplor banyak hal di lingkungan sekitarnya. Hal-hal tersebut akan menghambat anak untuk tumbuh menjadi anak yang memiliki rasa percaya diri, dan menjadikan anak menjadi anak yang tidak percaya diri.

3. Pola asuh permisif

Gunarsa (2002) menyatakan bahwa orang tua yang mengaplikasikan pola asuh permisif pada anaknya maka akan memberikan kekuasaan penuh pada anaknya tanpa menuntut kewajiban dan tanggung jawab pada anak, tetapi orang tua tidak dapat mengontrol perilaku anak secara maksimal karena orang tua dianggap hanya sebagai penyedia fasilitas pada anak. Dan tentunya orang tua dan anak kurang efektif dalam berkomunikasi. Orang tua yang menerapkan pola asuh permisif, akan berakibat pada perkembangan kepribadian anak yang kurang terarah, dan anak akan merasa mudah mengalami kesulitan jika dihadapkan pada aturan yang berlaku di lingkungan masyarakat.

Berdasarkan hasil pengamatan peneliti, sebagian besar keluarga di Desa Tanggeran, Kabupaten Banyumas yang memiliki anak usia dini, mereka menerapkan pola asuh demokratis. Dimana orang tua memberikan kebebasan pada anak tetapi masih tetap mengawasi anak atau tidak serta merta dalam membiarkan anak. Beberapa orang tua mendidik anak dengan membiasakan menggunakan bahasa Jawa dalam berinteraksi sejak anak usia satu tahun, ada juga orang tua yang membiasakan menggunakan bahasa Jawa dalam berinteraksi ada anak ketika anak sudah masuk PAUD, atau bahkan ada orang tua yang membiasakan menggunakan bahasa Indonesia dalam berinteraksi dengan anak sejak anak usia satu tahun sampai anak masuk PAUD. Pembentukan karakter pada anak akan berbeda-beda tingkatannya tergantung bagaimana orang tua menanamkan dan membelajarkan nilai karakter pada anaknya. Orang tua memiliki peranan 
yang sangat penting atau sebagai titik sentral dalam pembentukan karakter anak, walaupun ketika anak memasuki usia SD mereka akan lebih banyak berinteraksi dengan ligkungan sekitar, yakni teman sebayanya, dan orang dewasa di lingkungan tempat tinggalnya. Sebagai orang tua perlu terus mengawasi anak untuk menjadikan anak yang tumbuh dengan kepribadian yang baik. Pembentukan karakter dilakukan dengan pembiasaan menggunakan bahasa jawa pada anak, yakni pada saat berkomunikasi di lingkungan keluarga. Anak yang diajarkan dan dibiasakan untuk berkomunikasi dengan bahasa jawa di lingkungan keluarga, memiliki sopan santun yang lebih daripada anak yang dibiasakan berbahasa Jawa ketika ia memasuki dunia pendidikan (PAUD). Berbahasa Jawa secara tidak langsung akan mengajarkan sikap sopan santun pada anak, dan anak dapat lebih menghargai orang-orang di sekitarnya, seperti teman sebayanya, dan juga orangorang dewasa di sekitarnya. Orang tua memberikan stimulus pada anak mengenai pembiasaan penggunaan bahasa Jawa dalam kehidupan sehari-hari untuk berinteraksi dengan orang lain. Orang tua terlebih dahulu belajar bahasa Jawa dan terus belajar sampai benarbenar memahami sebelum mengajarkan pada anak, supaya tidak terjadi kesalahan atau kekeliruan dalam mengaplikasikannya. Ketika salah dalam mengaplikasikan pada anak, maka anak akan membawa kesalahan-kesalahan tersebut ke lingkungan yang lebih luas, yakni lingkungan masyarakat.

\section{Pendidikan Bahasa Jawa di Lingkungan Keluarga}

Penguasaan berbahasa pada anak dimulai sejak anak baru lahir, dan penguasaan bahasa Jawa akan lebih maksimal jika dikuasai oleh anak sejak ia dilahirkan. Seorang anak lebih mudah menguasai bahasa jika dilakukan melalui pembiasaan dalam berkomunikasi sehari- hari dengan mendengar komunikasi yang dilibatkan secara langsung. Keterampilan berbahasa yang baik perlu dimiliki oleh orang tua, dengan memberikan stimulus pada anak dalam perkembangan keterampilan berbahasa. Misalnya dengan cara berkomunikasi dengan anak menggunakan kata-kata yang baik dan mendidik, halus, dan selalu berusaha membuat anak merasa nyaman dan mempunyai semangat yang tinggi untuk belajar. Nilai moral yang dapat diambil dari bahasa Jawa yakni nilai kesopanan serta unggah-ungguh dan penguasaan tentang hal tersebut akan dimulai dari lingkungan keluarga, maka sebagai orang tua harus berhati-hati dalam berkomunikasi dengan anak dan lebih baik menggunakan bahasa Jawa yang baik dan benar supaya anak dapat mendapatkan stimulus positif untuk menerapkan bahasa Jawa dalam ia berinteraksi dengan orang di sekitarnya.

Bahasa Jawa ngoko lebih mudah didapatkan ketika anak mulai bermain dan berinteraksi dengan teman sebayanya. Anak dengan mudah dapat terpengaruh dengan bahasa yang dipakai oleh teman sebayanya atau ligkungan sosialnya. Jika sebagian besar teman sebayanya berinteraksi menggunakan bahasa Jawa ngoko maka si anak dengan mudah mengikuti bahasa temannya tersebut. Begitu sebaliknya, jika sebagian besar teman sebayanya berinteraksi menggunakan bahasa Jawa krama, maka si anak akan mengikuti bahasa yang diucapkan oleh sebagian temannya. Keterampilan berbahasa Jawa pada anak, khususnya bahasa Jawa krama perlu dilakukan pembiasaan yang berlangsung terus menerus.

Berdasarkan hasil pengamatan yang dilakukan oleh peneliti, masih jarang anak usia dini yang menerapkan bahasa Jawa krama dalam berkomunikasi dengan teman sebayanya. Mereka lebih banyak menggunakan bahasa Jawa ngoko, karena memang lebih mudah dipahami. Tetapi ada sebagian keluarga 
yang menggunakan bahsa Jawa krama dalam berkomunikasi dengan anak, tetapi ketika anak berada di lingkungan sekitar saat bermain dengan teman sebayanya maka dengan mudah anak mengikuti temannya dengan menggunakan bahasa Jawa ngoko. Perlu adanya pembiasaan oleh orang tua menggunakan bahasa Jawa krama dalam berinteraksi dengan anak, supaya dapat memberikan contoh pada anak kemudian anak akan meniru apa yang diajarkan oleh orang tuanya. Pola asuh yang cocok dalam pembiasaan penggunaan bahasa Jawa, baik ngoko atau krama yakni melalui pola asuh demokratis, dimana pola asuh demokratis sudah banyak diterapkan oleh orang tua yang berdomisili di Desa Tanggeran, Kabupaten Banyumas. Pola asuh demokratis tidak hanya membebaskan anak secara acuh, tetapi orang tua masih memberikan pengawasan dan memberikan arahan pada anak ketika anak melakukan kesalahan.

Pengenalan bahasa Jawa sejak dini pada anak perlu dilakukan guna melestarikan budaya Jawa. Di dalam bahasa Jawa terkandung nilai moral, nilai karakter yang berkaitan dengan sopan santun dan unggah ungguh dalam berkomunikasi dengan orang lain. Pengenalan bahasa Jawa pertama pada anak yakni melalui lingkungan keluarga. Orang tua harus memberikan stimulus positif mengenai pembiasaan berbahasa Jawa pada anak, ketika berkomunikasi dengan orang yang lebih tua diajarkan menggunakan bahasa Jawa krama, dan ketika berkomunikasi dengan teman sebayanya dapat menggunakan bahasa Jawa ngoko.

Pemakaian bahasa Jawa krama akan lebih mudah dilakukan jika mendapatkan dukungan dari lingkungan keluarga dan lingkungan masyarakat. Penanaman nilai karakter pada anak dapat dilakukan dengan mengajarkan anak bahasa Jawa krama melalui interaksi sehari-hari, dan pemberian arahan pada anak untuk menghormati orang lain, terutama orang dewasa yang ada di sekitarnya. Nilai karakter pada diri anak tercemin pada kaidah bahasa Jawa krama yang digunakan olehnya dalam berkomunikasi.

Berdasarkan hasil penelitian Handayani (2018) menyatakan bahwa pembiasaan penggunaan bahasa Jawa dapat mengimplementasikan nilai pendidikan karakter, yakni: sikap toleransi, sikap disiplin, sikap demokratis, sikap komunikatif, dan cinta kedamaian. Pembiasaan penggunaan bahasa Jawa dapat dilakukan dengan beberapa cara yakni melalui keteladanan dalam sehari-hari. Ketika anak memasuki usia sekolah perlu dilakukan pembiasaan pada siswa untuk memakai bahasa Jawa saat berkomunikasi dengan teman atau pendidiknya. Nilai karakter melalui pembiasaan berbahasa Jawa muncul pada perilaku baik kepala sekolah, pendidik, dan siswa.

\section{KESIMPULAN}

Pembentukan karakter pada anak usia dini dapat dilakukan melalui pembiasaan menggunakan bahasa Jawa dalam berinteraksi sehari-hari. Sebagian besar orang tua di Desa Tanggeran, Kabupaten Banyumas menerapkan pola asuh demokratis dalam menunjang perkembangan sikap dan tingkah laku pada anak. Pola asuh demokratis memudahkan anak dalam pembentukan karakter melalui pembiasaan bahasa Jawa dalam berinteraksi, karena orang tua tidak hanya membiarkan anak dengan memberikan fasilitas tetapi masih mengawasi dan memantau anak.

Anak usia dini di Desa Tanggeran, Kabupaten Banyumas sebagian besar berinteraksi menggunakan bahasa Jawa ngoko saat dengan teman sebayanya, tetapi ketika berada di lingkungan keluarga dan berinteraksi dengan orang dewasa yang lebih tua sudah mengaplikasikan bahasa Jawa krama walaupun sebagian masih ada yang menggunakan bahasa Jawa ngoko atau bahasa Indonesia. Keluarga menjadi titik 
sentral dalam pembentukan kebiasaan berbahasa Jawa pada anak, dengan pemberian stimulus yang positif maka akan terbentuk karakter pada diri anak melalui sopan santun dan unggah ungguh anak dalam berinteraksi dengan orang lain.

\section{DAFTAR PUSTAKA}

Apriliani, Elina Intan dan Dewi, N. K. (2019). Tata Krama Budaya Jawa Membentuk Sikap Santun Anak Usia Dini. 1(1), 35.

Creswell, J. (2015). Riset Pendidikan. Yogyakarta: Pustaka Pelajar.

Dardjowidjojo, S. (2010). Psikolinguistik. Jakarta: Yayasan Obor Indonesia.

Edward, C. D. (2006). Ketika Anak Sulit Diatur. Bandung: Mizan Media Utama.

Faisal, N. (2016). Pola Asuh Orang Tua dalam Mendidik Anak di Era Digital. An-Nisa', IX(2), 136.

Handayani, T. dan H. E. (2018). Implementasi Pendidikan Karakter Melalui Pembiasaan Penggunaan Bahasa Jawa Siswa di SD Karangmulyo Yogyakarta. Jurnal Pendidkan Ke-SD-An, 4(3), 418419.

Sochib, M. (2000). Pola Asuh Orang Tua. Dalam Membantu Anak Mengembangkan Disiplin Diri. Jakarta: Rineka Cipta.

Hurlock, E. B. (2000). Perkembangan Anak. Jakarta: Erlangga.

Sugiyono. (2013). Penelitian Pendidikan. Bandung: Alfabeta.

Gunarsa, S. (2002). Psikologi Perkembangan Anak dan Remaja. Jakarta: Gunung Mulia.

Yulianti, I. dkk. (2018). Penerapan Bahasa Jawa Krama Untuk Membentuk Karakter Sopan Santun di Sekolah Dasar. Prosiding Seminar Nasional. 